\title{
Pedogenesis of Mt. Sumbing Volcanic Ash above the Alteration Clay Layer in the Formation of Landslide Susceptible Soils in Bompon Sub-Watershed
}

\author{
Waode Asrianti Wida*, Azwar Maas and Junun Sarto Hadi \\ Department of Soil, Faculty of Agriculture, Universitas Gadjah Mada \\ Jln. Flora No. 1, Bulaksumur, Sleman, Yogyakarta 55281, Indonesia \\ *Corresponding author: wdasryantiwida@gmail.com
}

Received: $16^{\text {th }}$ December 2018; Revised: $26^{\text {th }}$ February 2019; Accepted: $12^{\text {nd }}$ March 2019

\begin{abstract}
Numerous studies on landslides have been carried out by many researchers. However, studies on physical properties of soil related to landslides potential in volcanic area are still rarely found. The objective of this study was to examine the effect of physical properties of soil on landslides potential. To collect the soil sample, sampling area method was applied. The soil type used in this study was the residual soil. The values of clay liquid limit, plasticity limit, plasticity index, water content, and COLE index were used to measure the physical properties of the soil. Organic materials were used as the supporting data. The results showed that the soil in the command area showed high value of clay which exceeded to $50 \%$. Such high level conditions in each profile affect the liquid limit; plasticity limit, plasticity index, water content, COLE index and organic material. Based on the results, it can be concluded that residual soils with significantly high clay values illustrated the risk of the formation of landslide fields in Bompon sub-watershed. The clay soil layer was the controlled factor of soil movement.
\end{abstract}

Keywords: Physical properties of soil, landslide potential

\section{INTRODUCTION}

The residual soil formed in hilly areas of Bompon sub-watershed is prone to potential landslide. The soil is generated from unmoving (in situ) weathering of soil mass with landslide potential, especially when the gradient of the soil layer is in the same direction as the slope. The development of residual soil does not always begin with weathering of the host rock. The growing residual soil is originated from weathering and alteration processes. Being in a transition zone from quarterly and tertiary volcanoes, the residual soil formed in Bompon sub-watershed has special characteristics (Pulungan, 2016).

The Bompon sub-watershed location is hilly in nature and contplasticity by massive landslide activities. It is also a landslides prone area that is mostly inhibited by the people. It has been utilized for various forms of land use. Most of them who use the land do not pay attention to the physical condition of the slopes which then leads to landslide potential. Most of the area surfaces is hills with slope angle of $8-45 \%$ (Masruroh, 2016). Such hilly surface is very influential to the landslide potential, because land surface is related to angles and slope stability (Masruroh, 2016).

Natural phenomena affect the dynamics of soil conditions. One of them is the alteration processes. Soil conditions formed from alteration processes have high clay content. The mechanism of alteration processes through altered breccia deposits due to the hydrothermal process is called the altered breccia (Pulungan, 2016; Budianto, 2016). Altered soil conditions will be very soft when saturated with water. Thus, their existence can be one of the factors of cont plasticity of landslides in Bompon Sub-watershed (Masruroh, 2016).

Soil is an important factor in the analysis of landslide susceptibility, especially from the soil physical aspects. Lands prone to landslides are closely related to the slope stability. The ground moves when the driving force is larger than the resisting force of the movement. The physical properties of soil such as texture, structure, consistency, porosity and color can be very influential for landslides to take place. Therefore, the soil undergoes degradation when 
there is deterioration in the physical properties of soil.

Such deterioration is possible when soil functions decrease. One of them is the structure damage. It results in landslides events under the following conditions 1) fairly steep slope, where the some volume of soil can slide down, 2) impermeable layer below the soil surface which is the slip plane, and 3 ) the existence of adequate water inside the soil that makes the soil layer above the impermeable become saturated (Arsyad, 2010). Approach of soil grain size, Atterberg limit and mineral composition affect the soil strength (Terzaghi, 1964). The particles shape and the amount of nucleus influence the movement of the soil (Lupini et al., 1981). The clay types, such as smectite, kaolinite, chlorite, and montmorillonite, are the slip planes in various types of landslides (Wen et al., 2007).

\section{MATERIALS AND METHODS}

\section{Study area}

Bompon sub-watershed is part of the Bogowonto River basin. It is astronomically located in the $49 \mathrm{M}$ zone $0396957 \mathrm{Mt}$ and $9164843 \mathrm{Mu}$. Bompon River flows to the south and passes through three villages in Magelang Regency: Kwaderan, Wonogiri, and Margoyoso. The administrative boundaries of the command are as follows: North Pandanretno and Bumbusari Village, Kajoran District; South: Mayungsari Village, Bener District; East : Madukoro Village, Kajoran District and Kaliabu Village, Salaman District; West: Wuwuharjo Village, Kajoran District.

Bompon sub-watershed is located in Bogowonto watershed system and is also part of Kulonprogo mountain range. Bompon subwatershed is 300 hectares, most of which are located in Wonogiri Village. It is also situated in Margoyoso Village sub-watershed, which is the downstream part of Bompon river flow.

Residual soil was used as the sample in this analysis by applying sampling area method carried out in the Talok, Bengkok, and Turbansari profiles within Bompon Sub-watershed area. The soil sample was taken from each layer from the lowest to the top layer within 2 meters in depth due to the thick soil solum and high clay value. The soil was dominated by high clay levels originated from the alteration processes and which fall in volcanic ash.

Sample analysis was carried out for physical properties of soil consisting of texture, liquid limit, plasticity limit, plasticity index, COLE index and soil moisture content. Chemical analysis of soil, which was the organic material, was used as the supporting data. Soil texture testing was carried out by applying pipette method. The testing of Atterberg limits such as liquid limit, plasticity limit, and plasticity index was carried out in casagrande method. The gravimetric method was used for testing the soil moisture content. The organic material testing applied the Walkey and Black method and COLE index testing applied the injection tube. Measurement of slope took a use of a clinometer. The analysis technique in determining the level of soil insecurity was the quantitative descriptive technique and quantitative descriptive applied the Ersoy's (2013); Gronbech's (2009); Harjowigeno's (1989); and Rachim's (2007) methods with modifications.

\section{RESULTS AND DISCUSSION}

Talok, Bengkok and Turbansari profiles showed the highest clay content in varying layers. The highest clay content was resulted from the existence of natural processes such as weathering and alteration processes. Weathering from the bottom to the top and alteration processes resulted in bottom-up and top-down processes (Pulungan, 2016). Both of these processes generated the formation of fluctuating clay values in each profile. Clay soil which was formed from fluctuation acted as the triggering factor of soil movement because clay could function as a sliding landslide field.

The highest values of liquid and the plasticity limits were not directly proportional to the highest clay value (Table 1). At layer 6, they were not followed by the highest level (Table 1) and not directly proportional to the highest level either. Such condition was contrary to the theory that liquid and plasticity limits would increase. It was estimated that soil grains were more refined as in clear soil (Hardiyatmo, 2012; White, 1942; Jain, 2015). The highest liquid and plasticity limits were not directly proportional to clay because they were affected by the water content. At the second layer, the water content was relatively low which was at $14 \%$ (Table 1). Such condition was supported by Li (2015) who explained that the amount of water content in clay soil was relatively low or smaller than $17.5 \%$. Reduction in water content was thought to be due to the evaporation and transpiration process of plants and most of the land was occupied with agricultural crops such as cassava 
Table 1. Analysis of clay texture, liquid limit, plasticity limit, and plasticity index Talok profile

\begin{tabular}{|c|c|c|c|c|c|c|c|c|c|c|}
\hline \multirow{2}{*}{ Profile } & \multirow{2}{*}{ Layer } & \multirow{2}{*}{$\begin{array}{l}\text { Depth } \\
(\mathrm{cm})\end{array}$} & \multicolumn{4}{|c|}{ Texture Class (\%) } & \multirow{2}{*}{$\begin{array}{l}\text { Plasticity } \\
\text { Limit (\%) }\end{array}$} & \multirow{2}{*}{$\begin{array}{c}\text { Liquid } \\
\text { limit (\%) }\end{array}$} & \multirow{2}{*}{$\begin{array}{l}\text { Plasticity } \\
\text { index (\%) }\end{array}$} & \multirow{2}{*}{$\begin{array}{c}\text { Water } \\
\text { content }(\%)\end{array}$} \\
\hline & & & Clay & Sand & Silt & & & & & \\
\hline \multirow[t]{6}{*}{ Talok } & 1 & $0-20$ & 78 & 9 & 13 & clay & 44.1 & 47.33 & 3.23 & 13.73 \\
\hline & 2 & $20-30$ & 88 & 9 & 3 & clay & 38.82 & 48.78 & 9.96 & 14.70 \\
\hline & 3 & $30-75$ & 78 & 7 & 15 & clay & 35.20 & 50.88 & 15.67 & 20.02 \\
\hline & 4 & $75-110$ & 78 & 6 & 16 & clay & 50.86 & 69.87 & 19.01 & 15.51 \\
\hline & 5 & 110-145 & 71 & 8 & 21 & clay & 54.28 & 68.04 & 13.76 & 17.60 \\
\hline & 6 & $145-180$ & 80 & 5 & 15 & clay & 70.07 & 76.89 & 6.81 & 20.69 \\
\hline
\end{tabular}

Table 2. The Analysis of clay texture, COLE index and organic material Talok profile

\begin{tabular}{|c|c|c|c|c|c|c|c|c|}
\hline \multirow{2}{*}{ Profile } & \multirow{2}{*}{ Layer } & \multirow{2}{*}{ Depth $(\mathrm{cm})$} & \multicolumn{4}{|c|}{ Texture Class (\%) } & \multirow{2}{*}{$\begin{array}{c}\text { COLE } \\
\text { Index }(\%)\end{array}$} & \multirow{2}{*}{$\begin{array}{c}\text { Organic } \\
\text { matter }(\%)\end{array}$} \\
\hline & & & Clay & Sand & Silt & & & \\
\hline \multirow[t]{6}{*}{ Talok } & 1 & $\begin{array}{l}0-20 \\
\end{array}$ & 78 & 9 & 13 & clay & 0.04 & 0.07 \\
\hline & 2 & $20-30$ & 88 & 9 & 3 & clay & 0.08 & 0.14 \\
\hline & 3 & $30-75$ & 78 & 7 & 15 & clay & 0.08 & 0.14 \\
\hline & 4 & $75-110$ & 78 & 6 & 16 & clay & 0.04 & 0.07 \\
\hline & 5 & $110-145$ & 71 & 8 & 21 & clay & 0.06 & 0.10 \\
\hline & 6 & $145-180$ & 80 & 5 & 15 & clay & 0.04 & 0.07 \\
\hline
\end{tabular}

and corn by means of tillage. However, albeit not directly proportional to clay, liquid and plasticity limits, clay soil was classified as soil in high plasticity as it reached $>85 \%$. This condition was strengthened by a research by Budianto, (2016) explaining that soil with $87.66 \%$ of clay was classified as fine-grained soil with very high plasticity index. That condition was closely related to the soil movement.

The plasticity index was not directly proportional to clay in Talok profile. The highest plasticity index and clay level were at layer 4 and 2 , respectively. The plasticity index was not directly proportional to clay due to the influence of water content. Decreasing water content was suspected because it was influenced by the evaporation and transpiration of plants. Water content of $14 \%$ was classified as low in layer two. The amount of water content in clay soil was relatively low, which was smaller than $17.5 \%$ ( $\mathrm{Li}, 2015)$. Decreasing water content was suspected either due to the soil pore that was not filled with enough water or the air that was trapped in the micro pore. A slight decrease in water content caused the soil to dry out and lost its plastic properties (Hardiyatmo, 2012). The plasticity index was not directly proportional to the level of clay as in the theory that plasticity index and clay content would also be high (Hardiyatmo, 2012). The plasticity index was influenced by the chemical content (Schmitz, 2004; Kyambadde, 2012).
The highest COLE index and clay value was found at Layer 2 (Table 2). Such condition is in line with the theory that the amount of clay in the soil is related to the increasing COLE index value (Widomski, 2018). Soil with higher clay content indicated larger degree of soil wrinkling (Notohadiprawiro, 1998). The highest COLE index and clay value were directly proportional due to the influence of organic material content. This was supported by Notohadiprawiro, (1998) explaining that the low organic material had high wrinkle power. Organic material in high clay and decreasing groundwater content would result in soil shrinkage (Tuduri, 2004). The organic material was classified as low on both layers in Talok profile (Table 2) due to fact that the command area which is in the hills required land management. The excessive tillage in crop cultivation would affect the presence of organic material in the soil. Such condition was also supported by Wita (2009) who explained that soil with low organic material would cause easy degradation of aggregates.

The highest value of the liquid limit, plasticity limit and plasticity index was directly proportional to the highest clay value and was found at layer 4 (See Table 3). They were directly proportional to clay due to the influence of the size of soil grains. Pulungan (2016) stated that the command area had fine grain size due to alteration processes. Soil with fine grain size, such as clay soil, had large surface 
Table 3. Analysis of clay texture, liquid limit, plasticity limit, and plasticity index in Bengkok profile

\begin{tabular}{|c|c|c|c|c|c|c|c|c|c|c|}
\hline \multirow{2}{*}{ Profile } & \multirow{2}{*}{ Layer } & \multirow{2}{*}{$\begin{array}{l}\text { Depth } \\
(\mathrm{cm})\end{array}$} & \multicolumn{4}{|c|}{ Texture Class $(\%)$} & \multirow{2}{*}{$\begin{array}{l}\text { Plasticity } \\
\text { Limit (\%) }\end{array}$} & \multirow{2}{*}{$\begin{array}{c}\text { Liquid } \\
\text { limit }(\%)\end{array}$} & \multirow{2}{*}{$\begin{array}{l}\text { Plasticity } \\
\text { index }(\%)\end{array}$} & \multirow{2}{*}{$\begin{array}{c}\text { Water } \\
\text { content }(\%)\end{array}$} \\
\hline & & & Clay & Sand & Silt & & & & & \\
\hline \multirow[t]{5}{*}{ Bengkok } & 1 & $0-20$ & 69 & 12 & 19 & Clay & 47.24 & 58.37 & 11.13 & 14.24 \\
\hline & 2 & $20-30$ & 76 & 6 & 17 & Clay & 59.45 & 70.16 & 10.7 & 22.4 \\
\hline & 3 & $30-75$ & 74 & 10 & 16 & Clay & 55.44 & 72.81 & 17.37 & 20.32 \\
\hline & 4 & $75-110$ & 83 & 5 & 12 & Clay & 61.08 & 82.66 & 21.58 & 23.76 \\
\hline & 6 & $110-145$ & 66 & 8 & 26 & Clay & 58.6 & 76.48 & 17.88 & 28.25 \\
\hline
\end{tabular}

Table 4. Analysis of clay texture, COLE Index and organic matter in Bengkok profile

\begin{tabular}{|c|c|c|c|c|c|c|c|c|}
\hline \multirow{2}{*}{ Profile } & \multirow{2}{*}{ Layer } & \multirow{2}{*}{ Depth $(\mathrm{cm})$} & \multicolumn{4}{|c|}{ Texture Class $(\%)$} & \multirow{2}{*}{$\begin{array}{c}\text { COLE Index } \\
(\%)\end{array}$} & \multirow{2}{*}{$\begin{array}{c}\text { Organic } \\
\text { matter }(\%)\end{array}$} \\
\hline & & & Clay & Sand & Silt & & & \\
\hline \multirow[t]{5}{*}{ Bengkok } & 1 & $0-20$ & 69 & 12 & 19 & Clay & 0.1 & 0.65 \\
\hline & 2 & $20-30$ & 76 & 6 & 17 & Clay & 0.08 & 1.4 \\
\hline & 3 & $30-75$ & 74 & 10 & 16 & Clay & 0.1 & 1.03 \\
\hline & 4 & $75-110$ & 83 & 5 & 12 & Clay & 0.13 & 1.5 \\
\hline & 5 & $110-145$ & 66 & 8 & 26 & Clay & 0.08 & 2.93 \\
\hline
\end{tabular}

area so that they can bind water despite its difficulty to pass through (Hardjowigeno, 2003). This was also supported by Handoko et al. (2015) describing that the highest value of $54.47 \%$ was classified as finegrained soil with high plasticity index. Furthermore, it was also strengthened by Ersoy (2013), that the $50 \%$ value indicated significant correlation with the liquid limit, plasticity limit and plasticity index. The values were directly proportional to the level according to the theory which stated that the level determination was based on the Atterberg limits (Liu, 2016). The liquid limit was positively related to the amount of nucleus and influenced by the clay content (Stanchi, 2016). The plasticity index and liquid limit were in contplasticity due to the clay content (Spagnoli, 2018). The plasticity index was determined based on clay content (Maroto, 2018). The liquid and the plasticity limits increased, and so did fine grains, expectedly (Hardiyatmo, 2012).

Liquid limit, plasticity limit, and plasticity index that were directly proportional to clay were closely related to the ground movement. This condition was evidenced by the results of previous studies indicating high liquid limit with clay $>50 \%$ in the landslide area of Bompon Sub-watershed (Masruroh, 2017). Bengkok profile reached $83 \%$ and was directly proportional to the liquid limit, plasticity limit, and plasticity index at layer 4 (Table 3). This condition was considered to be the plane of the ground movement. This was supported by Pulungan's study (2018) that alteration processes producing high yields became a slip plane for the landslides. This was also supported by the research from Handoko et al. (2015) in Sidoarjo. They concluded that the soil had landslide potential due to its compressibility influence. Soil which contained high water content and which was saturated would be compressed. Reduction in soil volume was due to loading results in land subsidence (Handoko et al., 2015). Furthermore, a straight comparison of the liquid limit, plasticity limit, and plasticity index to clay was also observed in Turkey by Ersoy et al. (2013) stating that the landslides potential was influenced by fine grain size, which had significant correlation as indicated by the clay value increasing linearly with the plasticity index. The higher the clay, the higher the aggregate and softening of the soil would be.

The COLE Index value was directly proportional to clay value and the highest values were at layer 4 (Table 4). Such condition was in accordance with the theory that higher clay content indicated greater degree of soil shrinking (Notohadiprawiro, 1998). The clay content was very influential because the clay surface was large and could absorb significant amount of water so that soils with high clay content were quite easy to develop and vice versa (Foth, 1994). The highest COLE Index and clay were directly proportional due to the effect of organic matter content. This was supported by Notohadiprawiro, (1998) stating that low organic matter provided high shrinkage power. Organic matter was classified as low at layer 4 in Bengkok profile (Table 4) which was influenced by the fairly open surface. Such condition caused it to rapidly decompose and thus, rapidly degraded and led to 
Table 5. Analysis of clay texture, liquid limit, plasticity limit and plasticity index in Turbansari profile

\begin{tabular}{|c|c|c|c|c|c|c|c|c|c|c|}
\hline \multirow{2}{*}{ Profile } & \multirow{2}{*}{ Layer } & \multirow{2}{*}{$\begin{array}{l}\text { Depth } \\
\text { (cm) }\end{array}$} & \multicolumn{4}{|c|}{ Texture Class (\%) } & \multirow{2}{*}{$\begin{array}{l}\text { Plasticity } \\
\text { Limit (\%) }\end{array}$} & \multirow{2}{*}{$\begin{array}{c}\text { Liquid } \\
\text { limit (\%) }\end{array}$} & \multirow{2}{*}{$\begin{array}{l}\text { Plasticity } \\
\text { index (\%) }\end{array}$} & \multirow{2}{*}{$\begin{array}{c}\text { Water } \\
\text { content }(\%\end{array}$} \\
\hline & & & $\overline{\text { Clay }}$ & Sand & Silt & & & & & \\
\hline \multirow[t]{7}{*}{ Turbansari } & 1 & $0-25$ & 53 & 18 & 29 & Clay & 52.23 & 59.32 & 7.09 & 12.59 \\
\hline & 2 & $25-50$ & 57 & 18 & 25 & Clay & 52.41 & 60.32 & 7.9 & 15.61 \\
\hline & 3 & $50-75$ & 51 & 13 & 36 & Clay & 72.05 & 79.92 & 7.87 & 25.66 \\
\hline & 4 & $75-110$ & 53 & 16 & 31 & Clay & 75.18 & 81.62 & 6.44 & 28.03 \\
\hline & 5 & $110-140$ & 60 & 10 & 29 & Clay & 62.97 & 76.74 & 13.76 & 20.59 \\
\hline & 6 & $140-170$ & 87 & 4 & 9 & Clay & 69.48 & 82.17 & 12.68 & 21.78 \\
\hline & 7 & $170-200$ & 60 & 11 & 29 & Clay & 66.23 & 77.71 & 11.47 & 21.57 \\
\hline
\end{tabular}

smaller amount of soil. Soils with low organic matter caused the slopes to be unstable when exposed to water. Furthermore, supported by a research from Brazegar, (1995), the density of high clay soil with low organic matter when undergoing a cycle of wetting and drying would affect the soil shrinkage. The higher the potential for the soil to swelling or shrinkage, the higher the softening of the soil would be. This condition caused the susceptible movement of the soil.

The liquid limit value was directly proportional to clay and the highest liquid limit and clay level was at layer 6 . This condition was in accordance with the theory that liquid limit was in contplasticity due to clay content (Barnes, 2013). Liquid limit was closely related to the soil surface area (Jefferson, 1998). It was directly proportional to clay because it was influenced by fine grain size. Soil dominated by high clay levels had large surface area. It also had narrow pore surface area which enabled it to bind water but it was difficult to pass (Hardjowigeno, 2003). The liquid limit was directly proportional to Clay due to the effect of fine grain size.

The command area indicating fine grain size resulted from alteration processes that produced high levels (Pulungan, 2016). This condition was supported by Zhang, (2007) that intensive magma activity mostly resulted in metal sulphide mineralization, which also indicated strong correlation to volcanic material (Taylor et al., 1986). The liquid limit was directly proportional to clay, as supported by Vithana (2012) that when it reached $73.2 \%$, it was classified as fine-grained soil with high plasticity. This condition was also supported by Smith et al. (1985) stating that value reaching $95 \%$ was classified as fine-grained soil with high plasticity.

Liquid limit was directly proportional to clay and closely related to landslide occurrence. The liquid limit was directly proportional to the clay level at layer 6 (Table 5) which was expected to be the plane of the ground movement. This was supported by a research (Pulungan, 2018) explaining that alteration processes producing high clay levels were the slip plane for landslides. Vithana (2012) research in Japan showed landslides potential because it was influenced by the nature of the soil undergoing normal consolidation. Thus, a reduction in soil volume due to loading would result in land subsidence. Furthermore, Smith et al. (1985) found that Israel is potential for landslides because it is affected by a significant correlation between the levels of the liquid limits. The higher the clay level, the higher the liquid limit would be to generate potential landslide.

Plasticity limit values were not always directly proportional to clay (Table 5). The highest plasticity limit was at layer 4. Meanwhile, the highest clay value was at layer six (Table 5). Plasticity limit was not directly proportional to the level of conflict under the theory, stating that plasticity limit is indicator used to measure the influence of the soil (Jefferson, 1998). Such high plasticity limit was in line with the increase of soil clay level (Hardiyatmo, 2012). The plasticity limit was not directly proportional to clay because it was influenced by soil water content, which reached $21.81 \%$ at layer 6 (Table 5). Such level of water content was classified as relatively low. This was supported by Wibowo (2011) who explained that the volcanic breccia weathering soil had low water content of $22.7 \%$. Reduction in water content was thought to be due to the influence of Sengon (Albizia falcataria) plant evapotranspiration. This was supported by Hudayana (2007) that Sengon plants experienced high evapotranspiration of $75 \%$ of the water content level of $50 \%-100 \%$, due to the influence of the physiological properties of the plants. Reducing the water content prevented the soil grains from getting closed to each other and the soil became cracked so that a decrease in soil took place. 
Table 6. Analysis of clay texture, COLE Index and organic matter in Turbansari profile

\begin{tabular}{lcccccccc}
\hline Profile & Layer & Depth $(\mathrm{cm})$ & \multicolumn{3}{c}{ Texture Class $(\%)$} & & $\begin{array}{c}\text { COLE Index } \\
(\%)\end{array}$ & $\begin{array}{c}\text { Organic } \\
\text { material }(\%)\end{array}$ \\
\cline { 4 - 7 } Turbansari & 1 & $0-25$ & 53 & 18 & 29 & Clay & 0.04 & 2.9 \\
& 2 & $25-50$ & 57 & 18 & 25 & Clay & 0.08 & 0.99 \\
& 3 & $50-75$ & 51 & 13 & 36 & Clay & 0.04 & 1.44 \\
& 4 & $75-110$ & 53 & 16 & 31 & Clay & 0.02 & 1.83 \\
& 5 & $110-140$ & 60 & 10 & 29 & Clay & 0.06 & 2.07 \\
& 6 & $140-170$ & 87 & 4 & 9 & Clay & 0.1 & 1.74 \\
& 7 & $170-200$ & 60 & 11 & 29 & Clay & 0.04 & 1.04 \\
\hline
\end{tabular}

Table 7. Classification of Landslide susceptibility level on various physical parameters of soil

\begin{tabular}{|c|c|c|c|c|c|c|}
\hline \multirow{2}{*}{$\begin{array}{l}\text { Landslide susceptibility, } \\
\text { Classification }\end{array}$} & \multicolumn{6}{|c|}{ Physical Properties of Soil } \\
\hline & $\begin{array}{c}\text { Slope } \\
\text { Gradient }\left({ }^{\circ}\right)\end{array}$ & $\begin{array}{l}\text { Clay } \\
(\%)\end{array}$ & $\begin{array}{c}\text { Liquid } \\
\text { limit }(\%)\end{array}$ & $\begin{array}{l}\text { Plasticity } \\
\text { limit (\%) }\end{array}$ & $\begin{array}{l}\text { Plasticity } \\
\text { Index }(\%)\end{array}$ & $\begin{array}{c}\text { COLE } \\
\text { Index }(\%) \\
\end{array}$ \\
\hline Unsusceptible & $<34$ & $<50$ & $<46$ & $<31$ & $<11$ & $>0.06$ \\
\hline Susceptible & $34-39$ & $50-70$ & $46-70$ & $31-60$ & $11-21$ & $0.06-0.13$ \\
\hline Highly susceptible & $>39$ & $>70$ & $>70$ & $>60$ & $>21$ & $>0.13$ \\
\hline
\end{tabular}

Source: Ersoy (2013); Gronbech (2009); Harjowigeno (1989); Rachim (2007); Melisa (2016) with modification

Table 8. Classification of soil physical characteristic to the landslide susceptibility in each profile

\begin{tabular}{|c|c|c|c|c|c|c|c|c|}
\hline \multirow[b]{2}{*}{ No. } & \multirow[b]{2}{*}{ Profile } & \multicolumn{6}{|c|}{ Physical Properties of Soil } & \multirow{2}{*}{$\begin{array}{l}\text { Susceptibility } \\
\text { classification of } \\
\text { soil physical } \\
\text { properties }\end{array}$} \\
\hline & & $\begin{array}{c}\text { Slope } \\
\text { Gradient }\left(^{\circ}\right)\end{array}$ & $\begin{array}{l}\text { Clay } \\
(\%)\end{array}$ & $\begin{array}{l}\text { Liquid limit } \\
\qquad(\%)\end{array}$ & $\begin{array}{l}\text { Plasticity } \\
\text { limit (\%) }\end{array}$ & $\begin{array}{l}\text { Plasticity } \\
\text { Index }(\%)\end{array}$ & $\begin{array}{c}\text { COLE } \\
\text { Index }(\%)\end{array}$ & \\
\hline \multirow[b]{2}{*}{1} & \multirow[b]{2}{*}{ Talok } & $34-39$ & 88 & 76.89 & 70.07 & 19.01 & 0.08 & \multirow{2}{*}{$\begin{array}{c}\text { Highly } \\
\text { susceptible }\end{array}$} \\
\hline & & susceptible & $\begin{array}{c}\text { Highly } \\
\text { susceptible }\end{array}$ & $\begin{array}{c}\text { Highly } \\
\text { susceptible }\end{array}$ & $\begin{array}{c}\text { Highly } \\
\text { susceptible }\end{array}$ & $\begin{array}{c}\text { Highly } \\
\text { susceptible }\end{array}$ & Susceptible & \\
\hline \multirow[b]{2}{*}{2} & \multirow[b]{2}{*}{ Bengkok } & $27-34$ & 83 & 82.66 & 6.08 & 21.58 & 0.13 & \multirow{2}{*}{$\begin{array}{c}\text { Highly } \\
\text { susceptible }\end{array}$} \\
\hline & & $\begin{array}{l}\text { Un-suscep- } \\
\text { tible }\end{array}$ & $\begin{array}{c}\text { Highly } \\
\text { susceptible }\end{array}$ & $\begin{array}{c}\text { Highly } \\
\text { susceptible }\end{array}$ & $\begin{array}{c}\text { Highly } \\
\text { susceptible }\end{array}$ & $\begin{array}{c}\text { Highly } \\
\text { susceptible }\end{array}$ & $\begin{array}{c}\text { Highly } \\
\text { susceptible }\end{array}$ & \\
\hline \multirow[b]{2}{*}{3} & \multirow[b]{2}{*}{ Turbansari } & $<27$ & 87 & 82.17 & 75.18 & 13.76 & 0.1 & \multirow{2}{*}{$\begin{array}{c}\text { Highly } \\
\text { susceptible }\end{array}$} \\
\hline & & $\begin{array}{l}\text { Un-suscep- } \\
\text { tible }\end{array}$ & $\begin{array}{c}\text { Highly } \\
\text { susceptible }\end{array}$ & $\begin{array}{c}\text { Highly } \\
\text { susceptible }\end{array}$ & $\begin{array}{c}\text { Highly } \\
\text { susceptible }\end{array}$ & Susceptible & Susceptible & \\
\hline
\end{tabular}

Source: Data Analysis (2017-2018)

The plasticity index was not directly proportional to the clay level and the highest was at layer 5 . Meanwhile, the highest clay value was at layer 6 (Table 5). The plasticity index was not directly proportional to the level, which was contrary to the theory stating that high plasticity index had highly fine grain size (Hardiyatmo, 2012). Fine-grained soils such as clay soil tended to have high water binding capacity (Utomo, 2012). The plasticity index affected the characteristics of aggregate strength (Osouli, 2016) and was not directly proportional to clay because it was affected by the relatively low water content. Condition of low water content was resulted from indequate water in pore or the air that was trapped in the micro pore. A slight reduction in water content caused the soil to dry out and lost its plastic properties (Hardiyatmo, 2012). Therefore, a decrease in the plasticity index was not directly proportional to clay.

The COLE index value was directly proportional to the clay value (Table 6). The highest values of COLE index and Clay value were found at layer 6 (Table 6). A straight and clear comparison of the COLE index was based on the theory that soil development and shrinkage potentials were closely related to the amount of nucleus in the soil. Expanding soil contains high clay content (Pairunan, 1997). The highest COLE index and clay value were directly proportional because they were influenced by organic matter. This was supported by Notohadiprawiro, (1998) explaining low organic matter 
Table 9. Cross tabulation of slope susceptibility and the soil physical properties parameter in Talok, Bengkok, and Turbansari Profiles

\begin{tabular}{|c|c|c|c|c|}
\hline \multirow{2}{*}{\multicolumn{2}{|c|}{ Slope }} & \multicolumn{3}{|c|}{ Soil susceptibility } \\
\hline & & Un-susceptible & Susceptible & Highly susceptible \\
\hline \multirow{3}{*}{ 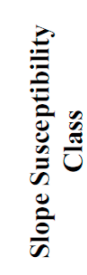 } & $\begin{array}{c}\text { Un- } \\
\text { susceptible }\end{array}$ & & Bengkok, Turbansari & \\
\hline & Susceptible & & & Talok \\
\hline & $\begin{array}{c}\text { Highly } \\
\text { susceptible }\end{array}$ & & & \\
\hline
\end{tabular}

Source: Writer, 2018. Note: green, yellow and red indicate unsusceptible, susceptible and highly susceptible, respectively.

had high shrinkage power. Organic matter in the six-layer of Turbansari profile was classified as low (Table 6). Low organic materially was influenced by high soil density, which was affected by alteration processes that produced high levels (Pulungan, 2016). Soil with low organic material caused slopes to be unstable when exposed to water (Hardjowigeno, 2003). High level was significantly related to COLE index. Clay that reached $76 \%-81 \%$ with COLE index of 0.05 led to land shrinkage (Gray, 2002) and resulted in susceptible movement of the soil.

The physical properties of soil in the command area included the classification of soil susceptibility with highly susceptible potential in each profile (Table 8). This condition was due to the deterioration of the physical properties of the soil occurred as evidenced by the analysis of various physical properties parameters of soil with the potential of highly susceptible landslides in each profile within the command area (Table 8). Such condition was supported by Rachim (2007) explaining that the range of $50-70 \%$ was classified as high. Furthermore, Ersoy (2013) explained that high levels of liquid limit, plasticity limit, plasticity index and COLE index were $46-70 \%, 31-60 \%, 11-31 \%$, and $0.06-0.2 \%$ respectively. Furthermore, Terzaghi (1964) in his research explained that the approach to measuring grain and Atterberg limits affected the strength of the soil.

Analysis of classification of slope susceptibility and physical properties of soil in Talok profile showed highly susceptible classification (Table 9) indicating high potential of landslide. The same analysis in Bengkok and Turbansari profiles included them into highly susceptibility classification.

\section{CONCLUSIONS}

High content of clay was found in the soil within the command area, in which the highest Clay reached more than $80 \%$ in each profile. Soil with high chemical content and slopes indicated a prone to landslides gliding. Analysis of slope susceptibility and soil physical properties in Talok, Bengkok and Turbansari profiles indicated that the location was classified as highly susceptible.

\section{REFERENCES}

Barnes. 2013. An apparatus for the determination of the workability and plastic limit of clay. Applied clay science., 80-81:281-290.

Barzegar, A.R. 1995. Effect of clay type and rate of wetting on the mellowing of compacted soils. Geoderma., 68:39-49.

Budianto, Y. 2016. Keterdapatan sensitiv clay pada lokasi longsor lahan di DAS Bompon, kabupaten Magelang, Jawa Tengah. Skripsi. Universitas Gadjah Mada. Yogyakarta.

Ersoy, H., M.B. Karsli., S. Cellek., B. Kul., I. Baykan and R.L. Parsons. 2013. Estimation of the soil strength parameters in Tertiary volcanic regolith (NE Turkey) using analytical hierarchy process. Department of Geological Engineering., 122:1545-1555.

Foth, H.D. 1994. Dasar-dasar ilmu tanah. Yogyakarta: Gadjah mada university press.

Gray, C.W. 2002. Correlations between shrinkage indices and soil properties in some New Zealand soil. Geoderma., 108:287-299.

Gronbech, G.L., N.N. Benjaminn and L.B. Ibsen. 2011. Comparison of liquid limit of highly plastic clay by means of casagrande and fall cone apparatus. Denmark: Department of Civil Engineering - Aalborg University, Aalborg. 
Handoko, L., A. Rifa'i, N. Yasufuku., R. Ishikura. 2015. Physical properties and mineral content of Sidoarjo mud volcano. Science Direct., 125:324-330.

Hardiyatmo, H.C. 2012. Tanah longsor dan erosi kejadian dan penanganan. Yogyakarta: Gadjah Mada University Press.

Hardjowigeno, S. dan Widiatmaka. 2007. Evaluasi kesesuaian lahan dan perencanaan tataguna lahan. Yogyakarta: Gadjah Mada University Press.

Jain, V.K. 2015. Correlation of plasticity index and compression index of soil. International Journal of Innovations in Engineering and Technology (IJIET).,

Jeferson. 1998. Liquid limit and the temperature sensittivity of clays. Engineering geology., 49: 95-109.

Li, Y.R., B.P. Wen., A. Aydin and N.P. Ju. 2015. Ring shear tests on slip zone soils of three giant landslides in the three gorges project area. Engineering Geology., 154:106-115.

Liu. 2018. Changes of Atterberg limits and electrochemical behaviors of clays with dispersants as conditioning agents for EPB shield tunneling. Tunnelling and underground Space Technology., 73:244-251

Lupini, J.F., A.E.Skinner and P.R. Vaughan. 1981. Drained residual strength of cohesive soils. Geotechnique., 31:181-213.

Masruroh, H. 2016. Membangun metode identifikasi longsor berbasis foto udara format kecil di DAS Bompon, Magelang, Jawa Tengah. Tesis. Universitas Gadjah Mada. Yogyakarta.

Maroto, M. 2018. What is clay ? a new definition of "clay" based on plasticity and its impact on the most widespread soil classification systemms. Applied clay science., 161:57-63.

Osouli. 2016. Effect of plasticity index and dust ratio on moisture-density and strength characteristics of aggregates. Civil Environmental Engineering., 9: 69-79.

Pairunan. 1997. Dasar-dasar ilmu tanah. Makassar: Badan ke-asaina perguruan tinggi negeri indonesia bagian timur.
Pulungan, N.A. and J. Sartohadi. 2018. New approach to soil formation in the transitional landscape zone: weathering and alteration of parent rocks. Environments., 5:1-7.

Rachim, D. A. 2007. Dasar-dasar ilmu tanah dan sumberdaya lahan. Bogor: Faperta IPB.

Schmitza., M. R., C. Schroedera., R. Charliera. 2004. Chemo-mechanical interactions in clay: a correlation between clay mineralogy and Atterberg limits. Science direct., 26:351358.

Singh, M. 2018. Chapter two- stabilization of soil organic carbon as influenced by clay mineralogy. Advances in agronomy., 148:33-84.

Smith, C.W., A. Hadas dan J.H. Koyumdjisky. 1984. Shrinkage and atterberg limits in relation to other properties of principal soil types in Israel. Elsevier science publishers., 35:47-65.

Spagnoli. 2018. Statistical variability of the correlation plasticity index versus liquid limits for smectite and kaolinit. Applied clay science., 156:152159.

Stanchi, 2017. Liquid and plastic limits of clayey, organic C-rich mountain soils: Role of organic material and mineralogy. Catena., 151:238-246.

Taylor, R.P., B.J. Fryer, . 1982. Rare earth element geochemistry as an aid to interpreting hydro thermal ore deposits, p. 357-365. In: A.M. Evans (ed). Mineralisation associated with acid magmatism. New York: John Wiley \& Sons.

Utomo, M. 2016. Ilmu tanah dasar-dasar pengelolaan. Jakarta: Prenadamedia group.

Vithana, S.B., S. Nakamura., S. Kimura., S. Gibo. 2102. Effects of overconsolidattion ratios on the shear strength of remoulded slip surface soils in ring shear. Engineering geology., 131-132:29-36.

Wen, B.P. 2007.Residual strength of slip zones of large landslides in the three gorges area, China. Engineering Geology., 93:82-98.

White, A.W. 1942. Atterberg plasttic limits of clay minerals. Public roads., 22:263-265.

Zhang, Y.S., Y.X. Qu, J.R. Liu. 2007. Engineering geological research on altered rocks in the area of NW Yunnan along Yunnan-Tibet Railway line., Chinese Journal of Geotechnical Engineering.,29:531-536. 